\title{
AN ANALYSIS STUDY ON THE NEED OF INVESTING IN THE CONTEMPORARY WAQF FIELDS ON THE KENYAN COAST
}

\author{
Ali Hemed Awadh ${ }^{1}$ \\ ${ }^{1}$ Lecturer School of Humanities and Social Sciences, Pwani University, Kenya. Bachelor in \\ Islamic law, (IUA) Master in Islamic Law (IUA) Ph.D. in Islamic law (IUA) Email: \\ a.awadh@pu.ac.ke
}

(Received: $25^{\text {th }}$ September 2021; Accepted: $24^{\text {th }}$ November 2021; Published: $31^{\text {st }}$ December 2021)

\section{Keywords:}

Investing;

Contemporary Waqf

Fields; Kenyan Coast;

\begin{abstract}
A B S T R A C T
This research entails highlighting the bases of Waqf in Islamic Jurisprudence; it also gives a historical view on the establishment of Awqaf in the Kenyan Coast. The researcher shall also highlight the traditional usage of Waqf usufruct, and finally he shall propose various contemporary Waqf fields in the Coast of Kenya, which people should invest in them to improve their living standards. Much has been invested in the tradional Waqf fields in the region, nothing has been invested in the contemporary Waqf fields to improve the living standards of the people of the Coastal Kenya, and this forms the problem of this research. The main objective of the research is to suggest the contemporary Waqf fields which need the people of the Coast to invest their Waqf cash on them to improve their living standards. Methodology used in this research is the induction method where ideas of scholars are analyzed and historical method. This method is used to narrate the advent of Muslims in the Kenyan Coast as
\end{abstract}


well as the establishment of the Awqaf in the region. The study revealed that there is need to invest in the contemporary Waqf fields to maximize the usage of regional waqf properties. The findings of this study would contribute to the understanding of challenges in utilization of Waqf property. It also contributes to the betterment of Waqf usage for the benefit of Ummah. The study recommends that, there is a need of initiating a collective Waqf projects (Waqfal-Jamai) through contributions from different donors to establish Waqf prjects, Ulamaas and preachers should create awareness on the importance of investing in the contemporary Waqf fields, seminars and research should be conducted on Awqaf.

Publisher All rights reserved.

\section{INTRODUCTION}

Waqf(Endowment) is a key Islamic institution, which has incorporated within its legal sphere vast areas of land within the Muslim world. It is a legal mechanism that has been recognized and developed under Islamic law (Shari'a) for more than a millennium. Under the Islamic legal the waqif, an owner permanently settles property, its usufruct or income, to the use of beneficiaries for specific purposes. At its heart, waqf is connected firmly with the religious precept of charity. Modern reforms in several Muslim countries have abolished nationalized or highly regulated awqaf. The eclipse of the waqf has left a vacuum in the arena of public services, which the State has been unable to fill easily in many Muslim countries. However, both the 'idea' of the waqf and the waqf doctrine itself remain influential and there are clear signs of its reinvigoration. The waqf served and continues to serve as an instrument of public policy and impacts on all aspects of Muslim life, including access to land. An evaluation of any future role for the Islamic waqf in strategies to improve the security of tenure is built upon an appreciation of its legal foundations, history, and socio-economic impact.

The waqf institutions weren't popular in all parts of the Muslim world. In West Africa, very few examples of the institution can be found and were usually limited to the area around Timbuktu, Djenné, and Masina. Instead, Islamic West African societies placed a much greater emphasis on non-permanent acts of charity. Early references to Waqf in India, can be found in the 13th century CE. Sultan Muizuddin Sam Ghaor (f. 1195-95 A.D.) dedicated two villages in favor of Jama Masjid, Multan, and, handed 
its administration to the Shaikhul Islam (highest ecclesiastical officer of the Empire). In the coming years, several more awqaf were created, as the Delhi Sultanate flourished.

The earliest pious foundations in Egypt were charitable gifts, and not in the form of a waqf. The first mosque built by the Companion 'Amr ibn al-'As(R.a) is an example of this: the land was donated by Kaysaba b. Kulthūm and the mosque's expenses were then paid by the Bayt al-Māl (state treasury). The earliest known waqf, founded by financial official Abū Bakr Muḥammad b. 'Al̄̄ al-Mādharā'̄i in 919 (during the Abbāsid period), is a pond called Birkat Habash together with its surrounding orchards, whose revenue was to be used to operate a hydraulic complex and feed the poor.

After the enactment of Islamic waqf law, Madrasah foundations were firmly established by the 10th century, the number of Bimaristan hospitals multiplied throughout Islamic lands. In the 11th century, every Islamic city had at least several hospitals. The waqf trust institutions funded the hospitals for various expenses, including the wages of doctors, ophthalmologists, surgeons, chemists, pharmacists, domestics, and all other staff, the purchase of foods and medicines; hospital equipment such as beds, mattresses, bowls, and perfumes; and repairs to buildings. The waqf trusts also funded medical schools, and their revenues covered various expenses such as their maintenance and the payment of teachers and students.

The first awqaf in East Africa Coast were mosques, graveyards, and small madrassas found in mosques for children to memorize the Quran. According to historians the first waqf to be established at the East African Coast was a Jamia mosque in the village of Shanga near the town of Lamu in the year 870 A.D. this mosque was small made of a tent, then wood, and later with stones and sand. In the $18^{\text {th }}$ century, the people of the East African coast benefited from other types of awqaf, the Muslim courts which were found in Islamic city-states like Mombasa, Malindi, Mnarani, Takaungu, and Kitoka.

\section{RESEARCH PROBLEM}

The Waqf property in the Kenyan Coast since its establishment in the $9^{\text {th }}$ Century in the region has been invested in traditional fields. There is no evidence of usage of the Waqf property in the contemporary fields .Therefore, there is a need to invest in the contemporary fields so that it can address different economic and social problems of the Coastal people to improve their standard of living.

\section{RESEARCH OBJECTIVES}

This research aimed at looking into the history of Waqf institution in Kenyan Coast. Enlighten the Muslim Ummah on provisions of Waqf in Islamic Law. It also highlighted on the the usage of Waqf in the tradional waqf fields in the region,and lastly suggested the contemporary 
Waqf fields which need the people of the Coast to invest their Waqf cash on them to improve their living standard.

\section{RESEARCH METHODOLOGY}

This study aimed at investigating current utilization of the Awqaf of the region. It's a descriptive research based on document analysis on previous articles and literature on waqf. Accordingly, the research adopted the qualitative approach whereby, an analytical study method is utilized. The researcher used the induction method where ideas of scholars were collected and analyzed and historical method where history of establishment of Awqaf in the region was highlighted. The data collected was based on the themes that were related to the utilization of waqf property. The data was coded into specific themes and analyzed.

\section{LITERATURE REVIEW}

The institution of Waqf was not confined to the time of Islam but was there even before the Islamic era. Awqaf in ancient human societies were dedicated to the temples, gods, cemeteries, clubs, and theaters. The income obtained from those Awqaf was used to pay the administrators and those who took care of them. The most significant areas of development of Waqfs in the ancient human societies are evident in the fact that they were dedicated to the temples, gods, cemeteries, clubs and theaters. The income obtained from those Waqfs was used to pay the administrators and those who took care of them. On the arrival of Islam, the need of investing on the Waqfs took a new form.

In the era of Umayyad and Abbasid caliphate, the Waqf usufruct was invested in establishing schools, libraries and writing of books. Vast fields of agricultural land were endowed for them. Thereafter, the income of the Waqf was used to establish universities such Qortoba in Andalus, Al Qarawey in in Morocco and Al Azhar in Egypt. The established institutions led to the spread of different fields of knowledge such as religion, literature, philosophy, medicine, astronomy and arithmetic. Ignorance was reduced due to the usage of Waqf and the development of knowledge was witnessed; which was spearheaded by the Waqf. In the areas of social welfare, the Waqf was invested in the care of widows and special houses were established for them with all necessities they needed. As a result, Islam superseded all civilizations in taking care of women. The Waqf was also directed to look at the welfare of the needy people, orphans and the poor, in order to meet all their essential needs. In protection and defending of the land, the Waqf invested in buying all the equipment and weapons needed by the soldiers.

The Islamic Waqf also allocated part of its income in setting free Muslim prisoners and Waqfs were invested in facilitating the movement of pilgrims to perform Hajj. The Islamic Waqf went further to help the society in establishing special hospitals to deal with deadly diseases such as leprosy, plague and others. Treatment in these hospitals was free of charge because it was catered for by the Waqf funds. 
In Egypt the Waqfs were used to establish Quranic schools in almost every Eyptian village. These schools provided free education, including Arabic and Islamic studies. The graduate of these schools were among the educated elite of the Egyptian society. The first awqaf in Malaysia were mosques, cemeteries and Madrasas used for public use. Waqf has been invested in contemporary fields such in food industry, tourism and fashion and lifestyle, which actively promote halal practices including halal foods and Islamic finance. In Kenya, the first Awqaf were the mosques, elementary schools, cemeteries and the Islamic courts which used to serve the Muslim minority.

\section{DEFINITION OF WAQF}

Literally, waqf (plural awqaf) comes from an Arabic word waqafa, which means "detention"(to prevent) "Confinement" and "to restrain" Technically, the jurists have given different meanings to Waqf. The Hanafis have defined it as "It is the detainment of a property ownership under the ruling of Allah (SWT) and giving charity from its income" The Malikis have said it is the usage of the benefit of the possessed property such as its income by a beneficiary for a duration specified by the donor. The Shafis have stated that "it is the detainment of the wealth, which might be beneficial by discarding its transaction and channeling its benefits to areas of righteousness as a way of getting closer to Allah". The Hanbalis have defined Waqf as "the detainment of the corpus and distribution of its benefit".

\section{The preferred definition}

The researcher views that; waqf refers to the detainment of both property and benefit under the ownership and ruling of Allah (SWT) and channeling its benefits to areas of righteousness as a way of getting closer to Allah (SWT).

The above definition has been preferred for the following reasons;-

a. There is no clear Qur'anic injunction forbidding endowment on the benefits. However, things in their originality are lawful if no evidence for their prohibition is found. Therefore, waqf can comprise both property and benefits.

b. The word benefit also refers to the utility. Consequently, the Islamic law has permitted waqf on properties such as a horse and a camel for the benefit of ridding on and milk respectively, a copy of the Quran and books of knowledge for the benefit of gaining rewards from Allah and knowledge respectively just like it has permitted waqf of a house and land for the benefit of dwelling. Therefore, the benefit is part and parcel of waqf.

c. Basically, waqf is a charity contract in which a donor intends to get closer to Allah (SWT) through it. Therefore, he is permitted by the law to endow on either benefits or properties. 


\section{LEGITIMACY OF WAQF IN ISLAM}

\section{LEGITIMACY OF WAQF IN QURAN}

There are no direct injunctions in the Quran ordering Muslims to create Waqfs, however, there are general verses that implicitly encourage Muslims to create Waqfs.

Among them:

"O you, who have believed, spend from the good things which you have earned and from that which We have produced for you from the earth. And do not aim toward the defective therefrom; spending [from that] while you would not take it [yourself] except with closed eyes. And know that Allah is Free of need and Praiseworthy". (Q2:267)

b)" ... and lend an excellent loan to Allah; and whatever good you send ahead for yourselves, you will find it with Allah..." (Q73: 20)

The above-mentioned verses refer to the meaning of spending and giving out charity to the charitable and humanitarian institutions in general which include waqf.

c) "Never will you attain the good (reward) until you spend (in the way of Allah) from that which you love..." (Q3: 92)

The Qur'an commentators (Mufasirun) have explained the word "spending" found in the above-mentioned verse to mean any act of righteousness which draws mankind closer to Allah (SWT) such as waqf.

\section{LEGITIMACY OF WAQF IN SUNNAH}

There are many Hadiths narrated from the Prophet which act as a base for the legality of Waqf, among them are:

a) Narrated by Ibn Umar (R.A) said: Omar (R.A) said to the prophet (SAW):" I have acquired a piece of land. Never have I acquired land more loved by me and more cherished by me than this (land from lands of khaibar). So what do you command me to do with it? Thereupon he (Allah's Apostle) said: If you like, you may keep the corpus intact and give its produce as sadaqah (charity).

The above hadith acts as a base on the validity of waqf

b)The prophet (saw) also said, "When a man dies, his deeds come to an end except for three things: ceaseless charity (Sadaqa jariyah), a beneficial knowledge, or a virtuous descendant who prays for him (for the deceased)."

The above hadith has not explicitly mentioned the term "waqf" in it, but the scholars say that the meaning of ceaseless charity "sadaqatul jariyya" mentioned in the hadith refers to waqf and the likes, which have longlasting benefits

c) It is also said: “... That Khalid (RA) endowed his breastplates in the way of Allah (SWT)." 


\section{LEGITIMACY OF WAQF IN IJMAA}

The scholars have agreed on the permissibility of waqf since the era of prophet's companions up to date. Moreover, history attests that both Abubakar (RA) and Umar (RA) have endowed a house in Madinah and a piece of land in Thamgh respectively. Uthman (RA) also endowed a well on the Muslims who lived at that time which benefited generation after generation whereas Ali bin Abi - Talib (RA) endowed his land in Yanbu' Just like Talha, Zubeir and Amru bin Aas (RA) endowed their houses; Anas bin Malik (RA) also endowed his in Madinah. Later on, other companions and their successors started endowing their lands and houses until waqf activities spread and became common among the Muslims. For instance, the companions' endowments were widely known in Madinah and other areas. For this reason, Jabir bin Abdullah (RA) said:" There was none among the companions who failed to endow a property".

\section{AWQAF IN THE KENYAN COAST.}

The history of endowments on the Kenyan coast dates back to the advent of Islam in this region. The first endowments in the Kenyan coast were mosques made of mud sand. This is because the early Muslims (Arabs) were business merchants who were not permanently living within the coast. They often use to come to the coast and set off for the Arabian Peninsula. The first endowment to be established in this region was the Friday congregational mosque at Shanga - a village in Pate Island in Lamu County, dating back to 870A.D. This mosque has been renovated more than twenty-five times, firstly, it was constructed using mud, then bricks, and lastly with bricks and lime. The first mosques in the Kenyan coast from the ninth century up to the end of the twelfth century were very small but were enough for a small group of worshippers because Islam was at its infancy stage and the Arabs who settled there were merchants, non-residents and they were not giving mosques due attention. After the establishment of the Islamic city-states along the Kenyan coast, the number of mosques increased to an extent where each city-state had a big number of mosques. For instance, the Islamic city-state of Gede - which is currently located south of Malindi - had a grand mosque and six other small mosques.

But after the arrival of the Portuguese on the East African coast in 1948A.D, their number started decreasing through demolition and burning. For instance, at Kilwa alone, they burnt three hundred mosques just like they destroyed mosques in Mombasa, Lamu, and Pate. After the collapse of the Portuguese rule, Omanis took over and ruled the coastal region from 1735 - 1838 A.D. During their reign, the number of mosques started increasing once again, because their leadership greatly helped to its construction. In addition, they also encouraged the locals to participate in their construction. As a result, fifteen mosques were constructed both in Mombasa and Lamu. 
Then, there came the rule of Boussaid, between 1838 - 1895 A.D the number of mosques increased as a result of the population increase. For instance, in Mombasa alone, their number reached twenty-five. Then, there came the British rule between 1895 - 1963 A.D, wherein the number of mosques increased and flourished because the British imperialists wanted to prevent locals from engaging themselves in governance and political issues leaving them busy with beautification and construction of mosques. Thus, the British imperialists were able to control the coastal society as they wished. During this reign, the number of mosques reached fifty-one and eighteen both in Mombasa and Lamu respectively.

Currently, the oldest mosque at the coast of Kenya which is still in use is the Pwani mosque (Msikiti wa pwani) in lamu which was established in the year 772 A.H/ 1370 A.D. The Kenyan coastal mosques are still leading in the dissemination of Islamic knowledge to the people through group studies where they study the translation of the Qur'an (tafseer), Arabic language, Islamic jurisprudence, and the Hadiths. The first advent Waqf of elementary school was at Shanga, where a ruin of an elementary Waqf school adjacent to the Friday mosque was found. Thereafter, many mosques at the Kenyan coast followed suit. These schools were mostly attended by children.

Moreover, the first cemetery Waqf at the Kenyan coast was also at Shanga near the Friday mosque dating back to 870 A.D while the first Islamic judicial courts to emerge at the coast of Kenya were during the rule of Omanis. Later on, more Islamic courts were established in every Islamic town such as Lamu, Malindi, Gede, Mnarani, Kitoka, Takaungu, and Mombasa. These courts were given a special status under the auspice of the Islamic city-states and were administered under Islamic law especially on personal issues such as marriage, divorce, and inheritance. The Waqf of elementary schools was later on replaced by the formal Madrasa, The first Islamic school which resembled a formal school was Riyadha Muslim School which was established in Lamu in the year 1901 A.D. In the beginning, it was an arbor in the form of a modern school. Later on, it was renovated and became a modern school comprised of students studying room (RibaT). The school program had two sessions that are the morning and evening sessions for both children and adults respectively. There was no complete curriculum; the emphasis was on the Qur'an commentary, Shafii Jurisprudence, and bases of hadiths and its sciences. Then, formal Muslim schools were established all over the coastal region with classes, curriculum, and syllabuses. The most notable among them were Ghazali and Falah in Mombasa and Najah in Lamu.

\section{TRADITIONAL FIELDS OF AWQAF ON THE KENYAN COAST}

The first awqaf on the Kenyan coast were mosques that sustained acts of worship, cemeteries, and later, Qur'an schools for Muslim women and children to memorize the holy Qur'an. This indicates the initial use of 
waqf in the development of society - religiously and culturally. Thereafter, the nineteenth century saw another type of waqf not known before emerged. It was the waqf of Sharia courts, given Muslims had no official body to resort to in legal matters. This waqf played a vital role in the development of legal awareness. However, priority was given only to the above-mentioned areas and not to economic and social areas. The operation of the sharia courts continued up to the twentieth century after the country's independence in $1963 \mathrm{AD}$, where they were abolished and the society lost one of the most important political and judicial components. This saw a strong influence of the secular law resulting in an integration of both societies.

The following is a breakdown of the utilization of the traditional awqaf on the Kenyan coast:

\section{Daawah field (Islamic missionary work).}

a) Restoration of existing mosques and construction of new ones to deliver religious sermons and lectures, issue juristic decrees (fatawa), conduct educational circles, and more to educate the community.

b) Printing religious pamphlets in local languages such as Swahili, Giriama, Digo, Taita, and Pokomo to help in presenting Islam better.

Second: The social field, which includes the following:

a) Distribution of food, clothing, and medicine to the needy and poor in regions such as Tana River, Lamu, and Kwale courtesy of the waqf of Tawfiq Muslim Youth and Muslim Education Welfare Association (MEWA) of Mombasa.

b) Caring for orphans - courtesy of the waqf of the Malindi Orphans Association in Malindi and the waqf of Chumani Islamic Center for Kilifi.

c) Remuneration of Imams and Muadhins.

\section{Health field}

a) Establishing centers to improve health conditions and treatment of serious diseases such as AIDS and rehabilitation centers for addicts. A few rehabilitation centers established are one in Mombasa, Mtopanga village courtesy of the waqf of the Muslim

Education Welfare Association (MEWA) and the other in Msabaha village, courtesy of the Malindi Education Development Association.

b) Health camps have been set up and medicine distributed to patients in Tana River, Kwale, and Kilifi courtesy of Tawfiq Muslim Youth.

c) Seminars were conducted in both Lamu and Mombasa to educate people on the effects of dangerous diseases such as AIDS.

d) A local radio station was established to educate the community on issues related to the coastal community such as the importance of peaceful coexistence among people of different religions and cultures and, urging the society to participate in state affairs such as politics, governance, education, and culture. 


\section{CONTEMPORARY FIELDS OF AWQAF ON THE KENYAN COAST}

There are different modern fields of awqaf, which when implemented on the Kenyan coast can lead to the development of its community. They include:

\section{Economic field.}

a) Establishment of modern awqaf such as tourist hotels, shops, stores, and residential buildings to increase the awqaf income. This project can be implemented by donors such as the Kenya Waqf Commissioners or any Waqif by establishing waqf investment funds for an investor (individual or a company), with permission to construct on Waqf commissioners' land tourist hotels, shops, stores, or residential buildings as per the agreed terms and conditions. However, the parties involved will share the income of those projects according to what they have contributed. Thereafter, the investor will gradually exit through the sale of his shares as agreed with the Wakf Commissioners of Kenya.

b) Setting an economic plan that seeks to meet societal needs such as the existing number of mosques, schools, hospitals, recreational centers like gardens, orchards, and public libraries for future planning in the entire Kenyan coast region. The plan will also help policymakers in knowing the socio-economic impact in this region of tourism and drug abuse. Once these plans are prepared, they will be presented to the donors for implementation.

c) Benchmarking of countries with advanced waqf system.

In many Muslim countries today, such as Kuwait and Sudan, endless efforts have been undertaken at individual and collective levels to sensitize Muslims on the significance of reviving the institution of waqf. These efforts have resulted in the growth and development of awqaf projects, some currently under construction. For instance, the General Authority of Islamic Affairs and Endowments in Sudan and the Kuwait Awqaf Public Foundation set up institutions, which they called awqaf projects and awqaf funds respectively. The objective of this project is to attract donations for specific projects or purposes such as the construction of hospitals, mosques, remuneration for Qur'an teachers, spreading of Islamic heritage and culture, and financing Islamic missionary work. However, this fund is not meant for a particular project but rather can serve any good purpose.

Therefore, by establishing "awqaf projects" or "awqaf funds" on the Kenyan coast, the establishment of universities, food and clothing factories, and other projects can be achieved. Furthermore, part of the income from the awqaf funds can be given to the coastal people as good loans to empower them economically given most of them are poor. Besides, the income can be used for in-service staff to be more productive in their undertakings. 


\section{Education Field.}

It includes:

a) Establishment of a full educational system (Kindergarten, primary, secondary, university, and post-university studies)

b) Training of teachers in various fields.

c) Establishment of literacy schools.

d) Establishment of artisan, vocational, and technical training schools.

e) Establishment of agricultural schools.

Below is enumerated as per the order of their importance:

\section{Establishment of a full educational system}

The importance of education in a society is clear and considered a means of pride and honor for its nation. Therefore, the Waqf money can be used to establish a full educational system from nursery to university and postuniversity studies, which follows curricula and courses, integrated with secular education to produce intellectuals who can freely interact with society.

\section{Training of teachers}

Waqf money can be used in establishing self-sustaining teachers' training colleges with management facilities and qualified trainers who will produce fully-baked graduates.

\section{Establishment of literacy schools}

These literacy schools can be established for different levels of society, such that adults with no literacy can benefit. They will join a special department dedicated to learning the basic principles of reading and writing. Seemingly, the curriculum should be integrated with Islamic subjects such as Jurisprudence, history, and others for the learner to freely interact with the members of the society. Therefore, there must be Waqf money to establish these schools, to set a curriculum and courses as per the learners' level, and to find trained and qualified teachers.

\section{Establishment of artisan, vocational, and technical training schools}

Most of the students graduating from secondary schools are employed in offices as subordinate staff or temporarily in teaching professions where opportunities are limited. Therefore, establishing artisan, vocational, and technical training schools will produce skillful self-employed youth thus, lowering the rate of unemployment in society.

\section{Establishing agricultural schools}

Kenya, like many other African countries, depends on agriculture as the backbone of its economy. So investing Waqf money in establishing agricultural schools in the Kenyan coast can help develop the country's economy.

However, the schools should practice farming, rearing livestock, and beekeeping given the Kenyan coast's fertile land, torrential rains, and 
moderate temperature. This highlights the importance of investing endowment in this field. Furthermore, the region is secure and also a tourist attraction which provides an easy and ready market for the produce.

\section{Health field}

a) Establishment of modern hospitals opens up services ranging from dialysis, organ transplantation such as kidney, heart, and liver, maternity, and rehabilitation of drug addicts. The project can be implemented using interest-free loans from banks. The income obtained from these hospitals can be used to provide scholarships for medical practitioners to better their services.

b) Purchasing of modern health equipment such as scanners, X-Ray machines, Ultrasound machines, surgical microscopes, C.T scan machines, Anesthesia machines, and Chemotherapy machines for cancer treatment as waqf for the hospitals using donations from the collective waqf (different donors). The income obtained from them can be used for different purposes such as giving scholarships to needy students and caring for orphans in the region.

c) Construction of residential buildings using donations from different donors (collective waqf) then, the proceeds are used to offer free medical camps to the coastal people.

\section{Religious and social field.}

a) Application of Islamic law such as the establishment of the local juristic society specifically for issuing decrees (fatawa) on important issues affecting the society such as approving or disapproving consumption of certain foods by Muslims, bearing in mind that the Muslim and non Muslim population in the Kenyan Coast. Issued decrees can be publicized using awqaf donations thereafter.

b) Establishment of a television station, which will help invite nonMuslims to Islam, seeing the diversity of religion and culture in this region. In this station, various misconceptions about Islam, which have hindered many people to embrace Islam such as Islam and Human rights, women in Islam, Jihad, Slave, and slavery, can be discussed. This project will be run by the proceeds obtained from a waqf project.

c) Establishment of public utilities such as gardens, libraries, street lighting, centers for caring widows, elderly persons, persons living with disabilities ( PWDS), maternity and family care as well as providing the public with essential needs using donations from different donors ( collective waqf).

\section{Cultural Fields}

The following are some of the cultural areas which need Waqf investment:

a) Establishment of public libraries.

b) Organizing Islamic missionary convoys.

c) Organizing Islamic workshops and seminars.

d) Issuing educational audiovisual tapes. 
The order of the following is per their importance:

\section{Establishment of public libraries}

Libraries are important, their significance vivid in society, and the nation can use them to encourage reading culture in society. However, it is worth mentioning here that there are a few public libraries in the major cities of Kenya. For instance, Mombasa has a single endowed library in the name of Seif Bin Salim Library - currently known as Kenya National Library, which is the largest library among other small libraries like Ibn Baz Library. Therefore, waqf money can be used to establish fully equipped public libraries.

\section{Organizing Islamic missionary convoys}

It is widely known that the Coast is a place with different religions and cultures. There is Islam - the oldest heavenly religion, Christianity, Hinduism, and some Jews. Additionally, there are also traditionalists and pagans. Thus, Islamic missionary convoys can be organized in the following ways:

I. By sending them to the outskirts of big cities predominantly inhabited by Muslims such as Mombasa, Malindi, and Lamu as well as to villages and rural areas such as Samburu, Kinango, Bamba, and Kiunga (a region located in the far north of the coast of Kenya). Missionary work of calling Muslims to adhere to the teachings of Islam today is equally important as calling non Muslims to Islam, knowing how Christians enjoy the state patronage, fully enhancing the Christianization process in the region. Consequently, calling Muslims to adhere to the teachings of Islam has become an obligation for every Muslim, which can help in building strong Muslim personalities capable of facing challenges in society.

As already mentioned above, the diversity in religion and culture in the Kenyan coast offers an opportunity for missionary convoys to grace it by way of religious debates with Christians, Hindus, and others. Competent Muslim scholars who know the errors in them can be featured. However, wisdom and good advice should prevail in such debates and the main goal should be an invitation to Islam and not to insult or reprimand them or for any other purpose.

\section{Organizing Islamic workshops and seminars}

Waqf money can be used to organize Islamic workshops and seminars to enlighten society on the basic principles of Islam. Moreover, workshops and seminars can help in creating awareness on the challenges facing the community such as the effects of drugs and drug abuse, tourism, and unemployment by providing society with amicable solutions. Furthermore, questions regarding acts of worship and societal relationships such as marriage can be dealt with in-depth. 


\section{Issuing educational audiovisual tapes}

We can use the waqf money to produce educative audiovisual tapes in different local languages to invite the coastal society to Islam. Since it tends to be innate in Islam in terms of morals and attributes, it will ease the process of calling them to Islam. The tapes can also be used to clarify misconceptions about Islam such as Islam and Human rights, Jihad, women in Islam, and other sensitive issues prevalent in the society.

\section{CONCLUSION}

Based on the research results, awqaf property can be a source of development for Muslims in general and the Kenyan coast in particular. The waqf has lost its significance in the modern era after having played a significant role in the life of Muslims for ages. For this reason, it must regain its place in the institutional construction of the Muslim society in our present day, and this can only through combining efforts of the Muslims. This research has come in this context, where it has tackled a significant topic, which has the likelihood of developing coastal society through its awqaf.

Firstly, the research has dealt with both literal and technical definitions of the waqf, highlighting its bases. The research also gave a historical cover-up on the establishment of the Awqaf in the region, giving a summary of the traditional usage of Awqaf in the Kenyan Coast, and lastly suggested the contemporary Waqf fields such as economic, educational, health, religious, social, and lastly cultural fields, which need people to invest on them to uplift the life status of the Coastal people.

This study revealed that there is need to invest in the contemporary Waqf fields to maximize the usage of regional waqf properties. The findings of this study would contribute to the understanding of challenges in utilization of Waqf property. It also contributes to the betterment of Waqf usage for the benefit of Ummah.

\section{RECOMMENDATIONS}

The research recommends the following:

1. There is a need for the establishment of collective awqaf(Al-WaqfAljamai) such as the establishment of the awqaf funds which many people can invest in creating different awqaf than the income from these awqaf can be channeled to support different areas and fields such as health and education.

2. Both scholars and preachers should spread correct religious awqaf awareness to the coastal community through seminars, lectures, speeches, and publications, which will help in explaining the importance and benefits of the awqaf.

3. Scholars, students of higher learning institutions, and researchers should conduct researches on awqaf by highlighting the problems faced by the awqaf and later provide amicable solutions.

4. The Islamic jurisprudence bodies should put interest in issuing decrees guiding investment in the awqaf funds in the light of contemporary fields 
and areas as priorities to improve the living standards of the Coastal people

\section{REFERENCES}

Al - Alusi (1985), Tafseer ruh al- maan. Beirut - Lebanon: Dar- al- Ihiyaa' alTurath al- arabi.

$\mathrm{Al}$ - Ammadi, Tafseer Abi- saud, Beirut - Lebanon: Dar- al- Ihiyaa' al-Turath alarabi.

Al - Buhuty (1997), Kashafi al - Qanai'. Makkah - KSA: Dar al - Mustafa al Baaz, 2nd ed.

Al - Jawhary, I. (1982), Aswihaah taaj lughat al- Arabia.

$\mathrm{Al}$ - Mani'i. A.S. Research in Islamic Economics.

Al - Mubarakfory (1990), Tuhfat al - ahwadh. Beirut - Lebanon: Dar al - Kutub al- Ilmiyah.

$\mathrm{Al}$ - Namri. K. S. (2000).Investment Companies in the Islamic Economy.

Al - Razi, T. (1996), Tarteeb al- Qamus al- MuhiT, Dar 'Alam al- Kutub , Riyadh $-\mathrm{KSA}, 4^{\text {th }}$ ed.

Al - Shawkan (1994), Fathu al-Qadir.Jeddah- Saudi Arabia: Dar al-Andalus, $1^{\text {st }}$ ed.

Al - Shawkan, Nail al- Awtwar, Beirut - Lebanon: Dar al - Kutub al- Ilmiyah.

Al- 'Ayni, M. (1980), Al- Binayatu fi sharhi al- Hidaya, Dar al - Fikr, Beirut Lebanon, $1^{\text {st }}$ ed.

Al- Alusi (1990), Al-Bahru al - MuhiT, Beirut - Lebanon: Dar al- Ihiyaa' alTurath.

Al- Fairooz Abady, M. (1991), Al- Qamus al- MuhiT, Dar al- Ihiyaa' al-Turath, Beirut - Lebanon.

Al- jazair A. (1997), Aisar Al-Tafsir. al - Madina al- Munawar - KSA : Dar- almaktabat al- uloom wal - hikam, $3^{\text {rd }}$ ed.

Al- Saa'd, Taiseer Kareem rahman fi tafseer kalam al- Mannan, Damam - KSA: Dar- adhakhairu,

Al Saad. S. A. (1420 A.H). Waqf in Islam, Its Role in Community Development. Jiddah, Kingdom of Saudi Arabia.

Al-Baghawi ,Sharhu sunnah, Beirut - Lebanon: Dar al - Maktab al- Islami.

Al-Qurtubi (1987), Al- Jamii' li ahkam al- Qur'an, Beirut- Lebanon: Dar Al Kitab Al Arab.

Al-urratu daghi.A.M.Renewal Theory of Waqf and its Investments.

An - Nawawi, (1995), Al- Majmoo', Cairo - Egypt: Dar Ihya turath al- arabi.

An -Nawawi. Sharhu Muslim, Beirut - Lebanon: Dar al - Kutub al- Ilmiyah.

As swawi, A. (1995), Bulghatu assalik, Dar al- Ihyaa al - kutub al- Arabiyyah, $1^{\text {st }}$ ed.

Assuyut (2001), Addur al - Manthur, Beirut - Lebanon: Dar- al- Ihiyaa' al-Turath al- arabi, , $1^{\text {st }}$ ed.

Aswan'ani, Subulu - Assalam. Beirut - Lebanon: Dar Ihya turath al- arabi,, $4^{\text {th }}$ ed.

Azzabidy,M. Taj al- 'Aroos min jawahir al - Qamus, Dar al - Fikr, Beirut Lebanon.

Berkey, J(1992) The Transmission of Knowledge in Medieval Cairo, Princeton: Princeton University Press.

Dhohayan,A(2001)Islamic Endowment and Its Role in Civilization Past,Present and Future,Madina: Al-Maathir Press.

Horton, M., Shanga. London: British Institute in Eastern Africa Publishing House. Ibn - Hazm, $A l-$ Muhalla, Beirut - Lebanon: Dar al-Fikr. 
Ibn Atwiyah (1993), Al- Muharar al - wajeez, Beirut - Lebanon: Dar al- Kutub alIlmiyah, $1^{\text {st }}$ ed.

Ibn Hajar al - 'Askalani (1996), Fath al- Bari, Cairo - Egypt: Dar Abi - Hayyan, $1^{\text {st }}$ ed.

Ibn Mandhur, J. (1990), Lisanu al- 'Arab. Beirut- Lebanon: Dar Swadir.

Ibn Qudamah, A. (1987), Al - Mughni, Dar Hijr. Cairo - Egypt.

Imam Fakhr al-Din al-Razi (1990), Al-Tafseer al- kabeer. Beirut - Lebanon: Dar al-Kutub al-Ilmiyah.

International Da'awa call (2004), Tawasul. International Da'awah publication house, Tripoli - Libya.

Islam, M. Z. (2012). Provision of Alternative Dispute Resolution Process in Islam. Journal of Business and Management, 6(3), 31-36.

Islam, M. Z. (2013). Legal enforceability of ADR agreement. International Journal of Business and Management Invention, 2(1), 40-43.

Kahf. M (2000). Islamic waqf development and management. Darul -Fikr, Damascus, Syria.

Kahf. M. Islamic Waqfs Development and Management.

Kahf. M. Waqf in Contemporary Islamic Society.

Khafagy,r.a (2007)Beyond Politics:Rolesof Islamic Endowments in Resisting Colonialism in Egypt(1882-1952)IN AWQAF, No 13

Levtzion, R. \& Pouwels, R. 1.The History of Islam in Africa.

Mahmoud, Al-fiqh al - Hanafi fi thawbihi al- jadid, Damascus - Syria: Dar alqalam, $1^{\text {st }}$ ed.

Muhammad, A, Ahmad, A and Ahmad, A. (1993), Al - Muqnii' wa sharhu alKabir, Dar Hijr , Cairo - Egypt, $1^{\text {st }}$ ed.

Muslim, Sahih Muslim, Cairo - Egypt: Dar al- Hadith

Nur Izzat,N.(2018) Waqf in Malaysia and its new waves in the Twenty-first Century, Kyoto Bulletin of Islamic Studies, No 11.

Saharanfury (1988), Badhli al - majhood, Cairo - Egypt: Dar Arrayyan. 